\title{
THE PINOY INVASION
}

\author{
Jov Almero \\ University of the Philippines Diliman \\ jovskyalmero@yahoo.com
}

\begin{abstract}
About the Author
Jov Almero received his Bachelor of Arts degree in Development Communication from Ateneo de Naga University, and he is currently working on his master's thesis as a Creative Writing student at the University of the Philippines Diliman. He was a fellow of the Silliman University National Writers Workshop in 2014. His works have appeared in Philippine Graphic and Likhaan: The Journal of Contemporary Philippine Literature.
\end{abstract}


There were snow globes everywhere: on Cassie's work desk, weighing down sheets of paper; on her bed stand next to a framed picture showing off a pair of eyes that most people considered cold, whereas he found it dreamy; on top of her closet, hand-painted in a postcard-worthy icy wonderland; resting on the television set switched to Arirang; flanking her snowflake night lamp; and on the idle spaces of her equally nippy tiled floor. The room was winter all over, and lying next to Cassie, John felt as though he was somewhere in the Swiss Alps, braving frostbite.

\section{The Subject: Prodigious Pinay}

Prodigious Pinay was born with a set of moles scattered from below the hairline all the way to the top of her cranium. It resembled the Philippine archipelago. To say she was intelligent would have been an understatement: she had learned her ABCs before she discovered the essential nimbleness to squat on a toddler's potty; she mastered the multiplication table ahead of her transition from feeding bottles to plastic cup; at the age of four, she was engrossed in a book called Marx for the Young-Adult-Like Tots; when she was eight-the youngest fifth grader in schoolshe wrote a paper entitled Santa Claus: Third World Dilemma; she skipped grades twice and graduated from primary school at the age of nine.

On her first day as a high school freshman, the Values Education teacher asked the class to write the essay How I Spent the Summer Vacation. Bored out of her wits with such an inane assignment, instead she wrote How I Spent My Summer Vacation Reading Signs of My Parents' Impending Annulment.

During the summer, her family went to Hong Kong for a four-day vacation. While her twenty-one-year-old brother enjoyed his tram ride, cable car ride, and roller coaster ride, Prodigious Pinay was busy speculating on her parents' peculiar gestures. On the surface, they were all sweet and squishy, but what her keen observation couldn't miss were the couple's awkward smiles and stolen glares. She didn't buy the happy-family-vacation scenes for a second. She would later on see that their family picture with Mickey Mouse and company from their Disneyland visit looked like the Last Supper. Only she couldn't decide as to who had betrayed whom.

Their parents announced their immediate, hopefully trial, separation a week after Hong Kong. Her mother was to migrate to Australia, while her father was to relocate to Dubai. She and her brother were given three choices: spend time with kangaroos in the Outback, camels in the desert, or an Aunt's three little rugrats in a cramped EDSA condominium. Her brother opted to stay in their apartment in Sta. Mesa since he had recently been offered a job. Prodigious Pinay chose to stay with her brother.

Kritika Kultura 24 (2015): -044

(C) Ateneo de Manila University

<http://kritikakultura.ateneo.net> 
The long-distance phone calls and consolatory packages followed.

The first year of their emancipation was challenging to Prodigious Pinay and her brother. It was especially hard for her to relate to him and all of his eccentricities. She couldn't understand how he could spend his days off work, on the couch, transfixed by the Pinoy Box Office channel. She couldn't fathom why he would rather play World of Warcraft instead of read a book about the Second World War. But what they lacked in the similarities that bound, they compensated for with their mutual fidelity, grounded in the awareness that they were each other's world.

Prodigious Pinay and her brother had spent special occasions as a pair since their parents' exit. Her eleventh birthday was different, though. When they arrived at Park's, her brother announced a third wheel was coming.

Her brother introduced her to his girlfriend. The three of them had a feast of authentic Korean food: miyeok guk (soup loaded with seaweed and beef brisket), doejji bossam (cabbage-wrapped pork belly in shrimp sauce), sengchai (shredded spicy white radish sprinkled with sugar, salt, rice vinegar, and minced garlic), $p a$ chae (scallion salad seasoned with sesame oil and sesame seed), gool jun (eggbattered oyster), and pa jun (scallion pancake). The dishes tasted like compounds produced after the methodical fusion of spices straight off the periodic table of kitchen elements. Prodigious Pinay's mouth felt like a chemist's lab with happy taste buds for scientists.

For dessert, her brother's girlfriend ordered samshin siru, layered cakes made from red beans. The siblings went on to enjoy the delicacy while the girlfriend watched with a stolid face. Prodigious Pinay asked why she wasn't getting her share. The girlfriend explained that in the Korean tradition samshin siru was served on a child's first birthday, and was offered only to members of the family, otherwise bad luck would befall the celebrant. Prodigious Pinay reasoned she was not celebrating her first birthday, took a piece from the tray, and placed the cake on the girlfriend's plate.

After a month, her brother's girlfriend, with her many snow globes, moved in with them.

\section{The Pawn: Pinhead John}

He had been mocked for having a head that was disproportionately small for his body. Bullies had given him various monikers including Knuckle Head King Kong, Shrunken Skull Master, and Super Silly Zit — because, apparently, his head looked more like an oversized pimple. The name that had stuck, though, was the rather straightforward Pinhead John. It was his least favorite. 
Pinhead John rectified his insufficient head mass with persistence. He would not stop unless a yoyo trick had been nailed, a complex mathematical equation had been solved, a stubborn blackhead had been popped, or an irresistible girl had said yes. Persistence had taken him a long way. But when his parents announced their cool-off, and he was left to take on the role of surrogate parent to his sister, he doubted whether his persistence was enough.

His persistence wouldn't have sufficed if it weren't for his sister's genius. One night he came home from work with takeaway dinner, only to see the dining table already set. His sister was grinning from ear to ear, and smugly said that pork adobo and steamed rice weren't rocket science. Their makeshift family, although odd and deficient, worked. A week before his sister's eleventh birthday he met a girl.

Pinhead John was poking around the shelves of National Bookstore for something that his sister would like. He was moving back and forth between the science and technology and history sections, when a girl whom he had almost mistaken for an ex-girlfriend approached him and asked what he wanted. He answered, "Anything the smartest girl in the world would love."

She came up with a hardbound copy of Rediscovering Erstwhile Treasures: The Pre-Apartheid Korea, authored by an English diplomat. The book had him at the words erstwhile and apartheid, whereas she had him at her allusion on the size of his shoes, and her nonchalance about the size of his head.

They spent the afternoon in a Korean tea house. The girl talked about her favorite Korean film, her job as English tutor to Koreans, and her love affair with snow globes. Pinhead John was spellbound.

It didn't take long before his girlfriend, with her many snow globes, moved in with him and his sister.

His girlfriend's predilection for Korean pop culture was something Pinhead John had known from the get-go. What he had not foreseen was how his sisterwho used to be more interested in stuff like the god particle than mainstream entertainment-responded to the Korean wave with such zeal. He suspected his sister had it in her all along - perhaps she, at her core, was an impressionable young girl just waiting to be saved from her formulas, diagrams, and conjectures.

It was comforting to see his sister appreciate things girls her age did: Korean pop stars with their penchant for gaudy apparel, flamboyant videos, and bilingual lyrics; Korean TV series with their mastery of scenes of piggy-back-riding couples; and Korean rom-coms with their typically cute and quirky premises. But he was worried that his sister's newly acquired taste for K-pop could get in the way of her studies. He was relieved when he came home one night to a homemade Korean dinner party complete with kimchi and soju, to learn that his little sister was at the top of her class honors list. 
Their family was outlandish and foreign, but nonetheless functional, and Pinhead John felt the urge to legitimize this set-up. He asked his girlfriend to marry him. She said no.

After three more attempts that elicited the same sub-zero response, Pinhead John started looking for things amiss.

One night, while his girlfriend was in the shower, he read through her cellphone messages. A message from her online student, Park Jam Pong, sparked his suspicion. It contained no more than a date, time, and place.

He tailed the cab she took all the way to Park's on the night specified on Park Jam Pong's message. At Park's his girlfriend exchanged bows with a spruced-up Korean guy who then pulled a chair for her at the farthest table from the reception area. They talked in a way people do when discussing their future together over a banquet of dishes so bright they hurt Pinhead John's eyes even from afar.

When she came home later that evening, she had three tickets to a concert by Korea's most famous pop star, Kim Bap. The gig was slated for the night before his sister's twelfth birthday. Pinhead John said he couldn't come.

The night of the concert, his girlfriend and sister wore matching ensembles. It was their take on typical Korean fashion: layered clothing, over-the-top accessories, and knee-high candy-colored boots. They were the weirdest duo, like major misfits on a strange mission.

As soon as the girls left, Pinhead John went to his girlfriend's work desk and switched on her laptop. He perused its contents but saw nothing except for downloaded files of Korean films, television series, and pop songs. He launched the Google mail window. An email address was still in the address box. He tried to guess the password. After an hour of unsuccessful hacking, he went to the kitchen and opened a bottle of soju. After another hour of persistent failure, he went to the living room, where he scanned a teen mag with Kim Bap on the cover. He switched on the television and scrolled through channels. Arirang flashed on screen.

Pinhead John typed thecoldestwinter in the password box. He was allowed access to his girlfriend's inbox which contained only one name: Park Jam Pong. He traced the message with the earliest date. He read a detailed narrative, the chilling ruse behind his romance.

\section{The Agent: Cold Case Cassie}

She had been working as a travel agent for a Korean company when, after a phone call from an irate client, she was summoned to her boss's office. Her boss didn't reprimand her as she had expected. Instead he told her about a job that, apparently, only she could do. At first she was hesitant, but when her boss agreed to her requirements in terms of remuneration she gave it a go.

Kritika Kultura 24 (2015): -044

(C) Ateneo de Manila University

<http://kritikakultura.ateneo.net> 
Cold Case Cassie, with her many snow globes, moved in with the pawn and the subject.

She worked like an automaton on a clockwork schedule: cook Korean dishes at dinnertime, play Korean movies after. Every morning, she would play a specific Kim Bap song loud enough to serve as the subject's wake up call. Every night, she would lie next to the pawn and dampen his potentially disruptive warmth with her cold embrace. In between these tasks, she pretended to online-tutor an English-challenged Korean businessman named Park Jam Pong. The mission was deceptively simple.

A month before the culmination of the mission, after watching her favorite Korean film The Coldest Winter with the pawn for the nth time-cuddling all throughout-the pawn pulled out a white velvet box from his pocket. He opened the box and revealed an engagement ring set with what looked like the tip of an icicle. The pawn uttered Cassie's favorite line from the movie and asked her to marry him.

Cold Case Cassie didn't even hold and admire the ring. She said no point-blank.

Later that night, the pawn came home drunk on what smelled like local beer. In bed he was shivering but refused the hug that she offered.

The last day of the mission was staged at Kim Bap's concert at the SM MOA Arena. There were thousands upon thousands of K-pop enthusiasts at the venue, waving banners, posters, neon light rods, and bouquets of flowers. Cold Case Cassie and the subject had the best seats. They were right in front of the stage, close enough to run to Kim Bap if they ever felt the urge. After almost an hour of palpable thrill, the lights in the concert arena went out, a collective gasp was heard, and a loud gong erupted, followed by Kim Bap's voice. The arena went wild.

On the second hour of the show, while the subject was awkwardly dancing and singing with Kim Bap, Cold Case Cassie was sweating profusely, fanning herself with a Kim Bap poster.

A few minutes before midnight, while Kim Bap was doing his thank-you spiel in fractured English, and the audience was expressing their communal love in misguided Korean, Cold Case Cassie ordered the subject to run to the exit. She told the subject that her brother had been mugged and was rushed to the hospital. The subject looked confused and for a moment, she seemed to weigh Kim Bap's merits against her brother's.

The subject dashed to the exit while Cold Case Cassie disappeared in the frantic crowd. 


\section{The Hypnotist: Officer Park Jam Pong}

Four years ago, Officer Park Jam Pong received a text message, at two in the morning, summoning him to the Prophetic Agency of Korea's (PAK) basement office at the Seoul Tower. PAK was Korea's alternative espionage outfit composed of wise elders who were descendants of the Koryo Kingdom's shamanic families.

When Officer Park arrived at the meeting room, he was received by 18 elderly women in their vibrant hanbok, and his middle-aged superior from the National Intelligence Service (NIS), in a three-piece black suit. They were all huddled in front of a long table upon which a wide scroll was laid. The scroll contained what looked like obscure ancient calligraphy.

His NIS superior didn't waste time on pleasantries and introduced Officer Parkrepresentative from the NIS's alternative preemptive damage control team named Bureau of Hypnosis $(\mathrm{BoH})$ - to the wise women. He then hurried to the details of the wee-hour official rendezvous.

The previous night, a prophecy which the PAK women had worked on for half a decade was completed. The final analysis revealed that in the year 2050, a South East Asian country would become one of the world's superpowers. It would be led by a middle-aged woman with an elaborate mole on her cranium. The mole would resemble a sitting dog. During her rule-a time when the world's geography had drastically shifted-her republic would be in conflict with South Korea over the legal jurisdiction of an island that had sprouted in the course of the tectonic change. The island would be in tangential proximity to the two opposing countries, and the dispute would trigger a war which South Korea was prophesied to lose.

The NIS, PAK, and BoH launched a preventive plot to address the looming dilemma. The plot, which was one year in the making, had two stages. The first stage involved the manufacturing of a Korean pop star. The second stage was the employ of a Filipina to infiltrate the dela Cruz household.

Upon the accomplishment of the plot's first stage, Officer Park travelled to the Philippines, in the guise of a businessman, for the commencement of the plot's second stage whose jump-off point was the appraisal of the type of girls John dela Cruz was drawn to. Once that had been adequately summed up, Officer Park began the hunt for his agent.

The girl who passed the rigid screening process was a BPO agent who moonlighted as an English tutor named Cassandra Dimalanta. According to her personal records, Cassandra Dimalanta's OFW-turned-activist parents were killed when she was nine. She heard the news over the phone, while watching the Korean war romance film The Coldest Winter.

Officer Park hired Cassandra Dimalanta as his pioneer travel agent, offering her an irresistible paycheck better than what she had received from her BPO and tutoring stints combined. When he finally revealed the plot, Cassandra Dimalanta didn't show any hint of surprise. Instead, she specifically asked for three provisions

Kritika Kultura 24 (2015): -044 
in exchange for her services: a permanent Korean residence VISA, a house in The Coldest Winter's film location, and a job nearby.

The plot's final stage began at a bookstore.

Soon after, Cassandra Dimalanta, with her many snow globes, moved in with the dela Cruz siblings.

The plot was almost flawless, until Cassandra Dimalanta succumbed to the most potent counter-hypnosis, the kind that had existed way before dynasties and civilizations - the one that had always overturned fate and prophesies. Officer Park and his superiors had thought Cassandra was too cold for such a dreadful cliché.

He noticed Cassandra Dimalanta's reversal during their last meeting at Park's. Whereas during their previous dinner trysts, she ate whatever it was he had ordered, this time she insisted on something from the menu which, from a culinary connoisseur's perspective, could only be deemed mediocre. Also, basic command of the chopsticks proved so challenging for her shaky hands that she had to ask for a spoon to shovel food into her mouth. After the meal, he handed her three concert tickets and when the agent did not try to outbow him as they said their goodbyes, he knew something was terribly off-kilter.

The night of Kim Bap's concert, a few minutes before the pop star could sing his new single with lyrics that had been stuffed with propaganda-the finale for the series of hypnoses geared to condition young Filipinas' psyche-Cassandra Dimalanta abandoned the plot, and roused Filipinas back to her senses.

Cassandra Dimalanta and the siblings disappeared after the concert. Officer Park was summoned back to Korea upon the plot's failure. He quit his BoH post, and with the aid of his hypnotic prowess, single-handedly launched his career as a Korean pop star.

\section{The Sell Out: Sook Ying Sum}

Sook Ying Sum belonged to an indie music scene called snowgazing. This alternative rock sub-genre was characterized by the fusion of droning riffs and layered vocals. It could only be compared to a spur-of-the-moment prayer. In a flash of musical transcendence, snowgazers were inclined to raise their heads toward the sky as if awaiting the maiden drop of snow.

No one listened to them.

After years of futile attempts to grab something substantial out of snowflakes, Sook Ying Sum was approached by a group of sponsors who offered him nothing less than stardom. Running low on soju, noodles, and rent money, and yearning to finally get the chance to perform for a real audience composed of more than five individuals who fell outside the spectrum of his bleary-eyed spectators, he signed the deal.

Kritika Kultura 24 (2015): -044

(C) Ateneo de Manila University

<http://kritikakultura.ateneo.net> 
Song Ying Sum's financiers hired a group of professionals that included a plastic surgeon, stylist, PR specialist, and a music producer. It took an entire year before he released his first single and music video. It was a viral success and in a matter of weeks, Sook Ying Sum was transformed from an unknown snowgazer to a household name whose pictures were pasted onto family's kitchen fridge. This time, he was already known as Kim Bap.

The chart toppers, mall tours, television appearances, radio guestings, magazine covers, and advertisements came, alongside the nightmares. At the height of his popularity, Kim Bap repeatedly dreamt of scenes of a bloody war on a snowfield that would culminate with a faceless man saying "write the bow" over and over.

Months before his first year anniversary as a pop phenomenon, Kim Bap wrote a song called "The Bow." He bargained with his handlers for creative freedom and to his surprise, they let him have his way. He went back to his snowgazing roots and composed the most wistful melody to accompany what he, all along, thought were lyrics to a love song.

"The Bow," carrier single of his sophomore album Winter Waiting, was launched during his first concert outside Korea. The song was a phenomenal failure. Not even the sole person for whom the song was intended was able to hear it. The pop star's nervous breakdown ensued.

Kim Bap was forgotten by the public, while another pop star took over his reign. He lost his voice, and had to be admitted, according to several press releases, to a monastery in Tibet to counter the spell of post-stardom catatonia. But rumor has it that he entered a rehab facility.

\section{The Snowgazers}

After weeks of hiding, the dela Cruz siblings sought help from the Philippine authorities. Their account of the South Korean prophecy was, at first, received with overt distrust and mockery. That was until Philippines' unnamed, undermined, and unofficial prophetic branch, which was composed of volunteers from various sectors of society, validated the prediction. Apparently, the group had known it all along, but the foresight had been repeatedly dismissed by high-ranking officials from the National Bureau of Investigation (NBI), who fancied themselves as the logical lot. With the anonymous group's aid, PAK's efforts to track the whereabouts of the siblings had been consistently intercepted.

The government sent the siblings to an undisclosed location with their absentee parents' consent. Before their departure, John visited National Bookstore and hoarded titles from the Filipiniana section. He also raided the shelves of a record store for OPM albums, and downloaded Pinoy movies including those by Brocka, Bernal, and de Leon.

Kritika Kultura 24 (2015): -044

(C) Ateneo de Manila University

<http://kritikakultura.ateneo.net> 
Six months after their exile, the day before Pinay's thirteenth birthday, while John was cooking adobo and Pinay was watching the film Himala-the doorbell rang. The siblings, who weren't expecting any visitors, cautiously went outside and on the doorstep they saw a small box. John picked up the box and untangled the band that held the stiff flaps of paper together. When they laid eyes on its content, a faint smile fleetingly crossed their faces. It was, after all, their first snow globe.

The year's first snowfall began. The siblings ran outside where they were no longer shielded from the snow, intent to frolic in winter's coming. They tilted their heads and raised their arms toward the white-speckled sky. To the accumulating snow at their feet, and the potential perils of a strange season, they refused to bow down. 